\title{
Pembelajaran Matematika Berbantuan Media Edmodo dalam Upaya Meningkatkan Kemampuan Pemecahan Masalah Matematika Siswa Kelas XI IPS 2 SMA Negeri 2 Tambun Selatan pada Materi Limit Fungsi Aljabar
}

\author{
Farah Ayu Maulidina ${ }^{1, \text { a) }}$, Pinta Deniyanti S. ${ }^{2, \text { b) }}$, Lukman El Hakim ${ }^{3, c)}$ \\ ${ }^{123}$ Universitas Negeri Jakarta

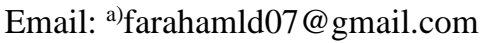

\begin{abstract}
Abstrak
Penelitian ini bertujuan untuk mengetahui keefektifan pembelajaran matematika dengan model $e$ learning menggunakan Edmodo dalam meningkatkan kemampuan pemecahan masalah matematika. Penelitian ini termasuk ke dalam penelitian tindakan kelas (PTK). Tindakan dilakukan dalam 3 siklus dengan total 10 pertemuan. Subjek dalam penelitian ini terdiri dari 6 orang siswa kelas XI IPS 2 SMAN 2 Tambun Selatan dari setiap kategori kemampuan pemecahan masalah. Instrumen yang digunakan dalam penelitian ini adalah observasi, wawancara dan tes kemampuan pemecahan masalah matematika. Analisis dilakukan secara deskriptif kualitatif dan kuantitatif. Hasil penelitian memperlihatkan bahwa terdapat peningkatan motivasi belajar dari keenam subjek penelitian sehingga pembelajaran matematika berbantuan Edmodo mampu meningkatkan kemampuan pemecahan masalah matematika siswa. Nilai rata-rata keenam subjek dan persentase ketuntasan belajar yang terus meningkat dari siklus I hingga siklus III dengan persentase tiap butir indikator pemecahan masalah dari siklus I hingga siklus III adalah sebagai berikut: (a) kemampuan memahami masalah meningkat dari 79,17\% menjadi $88,89 \%$, (b) kemampuan memilih strategi pemecahan masalah yang tepat meningkat dari $77,08 \%$ menjadi $97,22 \%$, (c) menyelesaikan masalah dengan menerapkan strategi yang telah ditentukan meningkat dari $66,67 \%$ menjadi $86,11 \%$, (d) verifikasi dan interpretasi hasil meningkat dari 66,67\% menjadi 77,78\%. Dapat disimpulkan bahwa pembelajaran menggunakan Edmodo efektif untuk meningkatkan kemampuan pemecahan masalah matematika siswa.
\end{abstract}

Kata kunci: kemampuan pemecahan masalah, e-learning, edmodo

\section{PENDAHULUAN}

Kemampuan pemecahan masalah merupakan hal yang perlu dimiliki oleh siswa. Upaya yang dapat dilakukan dalam meningkatkan kemampuan tersebut adalah dengan menciptakan pembelajaran yang efektif dan efisien. Menurut Polya (1957) kemampuan pemecahan masalah dibagi menjadi empat tahapan, diantara yaitu kemampuan memahami masalah, menentukan strategi pemecahan masalah, menyelesaikan masalah dengan menrapkan strategi yang dipilih, dan verifikasi serta interpretasi hasil penyelesaian. Di masa pandemi ini, pembelajaran matematika dinilai kurang optimal sehingga berpengaruh terhadap kemampuan pemecahan masalah siswa. Baik siswa dan guru masih belum terbiasa dengan suasana pembelajaran jarak jauh. Hal tersebut berdampak pada kurangnya pemahaman siswa terhadap materi yang disampaikan oleh guru. Hal ini didukung oleh hasil tes awal kemampuan pemecahan masalah yang dilakukan yang menunjukkan bahwa kemampuan pemecahan masalah matematika siswa kelas XI IPS 2 SMA Negeri 2 Tambun Selatan masih tergolong rendah dengan persentase $71 \%$ siswa yang belum berhasil memperoleh nilai di atas $\mathrm{kkm}$ dan tergolong dalam kategori 
kemampuan pemecahan masalah yang rendah. Oleh karena itu diperlukan inovasi dalam pembelajaran selama diberlakukannya pembelajaran jarak jauh ini. Salah satu hal yang dapat menarik minat belajar siswa selama PJJ adalah dengan penerapan model e-learning dengan berbantuan platform Edmodo. Namun penggunaan Edmodo ini masih sedikit diterapkan oleh guru.

Yustinaningrum (2018) mendefinisikan model pembelajaran e-learning sebagai model pembelajaran yang menggunakan perangkat atau instrumen lain berbasis software seperti aplikasi, website, dan lain-lain. Materi dapat digambarkan dalam berbagai bentuk yang lebih hidup dan interaktif sehingga mampu menciptakan suasana baru dalam pembelajaran. Dengan demikian, pembelajaran matematika memiliki potensi untuk membuat atmosfir dalam sebuah pembelajaran menjadi lebih berarti dan menyenangkan.

Berdasarkan penjelasan Hanifah, Supriadi, dan Widyastuti (2019) Edmodo dikembangkan oleh Nicolas Borg and Jaff O'Hara sebagai platform pembelajaran untuk berkabolarasi dengan pendidik dan guru dalam berbagai konten pendidikan. Adanya platform pembelajaran ini diharapkan dapat mengurangi penggunaan internet yang negatif ke arah yang positif. Penggunaan platform ini juga dapat mengurangi banyaknya penggunaan kertas, karena semua tugas yang diberikan akan diberikan dan dikumpulkan dalam bentuk soft file. Berbagai fitur yang tersedia pada Edmodo juga diharapkan mampu menunjang tiap proses pembelajaran. Sayangnya Edmodo belum menyediakan fitur video conference sehingga komunikasi hanya terbatas pada chatting.

Efektivitas pembelajaran merupakan suatu kondisi dimana adanya suasana pembelajaran yang interaktif sesuai kriteria pembelajaran yang efektif sehingga tercapailah tujuan pembelajaran (meliputi pengetahuan, sikap dan keterampilan) yang telah direncanakan baik oleh guru maupun satuan pendidikan. Hal ini didukung oleh definisi efektivitas pembelajaran menurut Rohmawati (2015) merupakan standar ketercapaian sasaran belajar dilihat dari adanya hubungan timbal balik siswa dengan guru maupun antara siswa dengan siswa lainnya terkait dengan pembelajaran. Carroll dalam (Rintaningrum, 2016) berpendapat bahwa efektivitas pembelajaran dipengaruhi oleh (a) sikap yang diukur dari waktu yang dibutuhkan untuk belajar, (b) ketekunan yang diukur dari minat belajar siswa dalam aktivitas belajar, (c) kesempatan untuk belajar diukur dari waktu yang diberikan, (d) kemampuan dalam memahami pembelajaran yang dilihat dari kemampuan siswa menyelesaikan tugasnya, dan I kualitas pengajaran yang ditinjau dari kemampuan guru dalam melakukan manajemen kelas.

Penerapan tindakan setiap penelitian ini dimaksudkan agar siswa lebih termotivasi dalam belajar sehingga menciptakan suatu pembelajaran yang aktif dan efektif. Pembelajaran aktif diharapkan mampu menumbuhkan potensi siswa hingga memperoleh hasil belajar yang optimal. Selanjutnya potensi yang dimiliki siswa dikembangkan dengan harapan memperoleh kompetensi belajar yang baik. Kompetensi belajar yang baik tersebut merupakan tujuan dari pembelajaran yang efektif.

Berdasarkan penelitian yang dilakukan oleh Hanifah, Supriadi, dan Widyastuti (2019) menyatakan bahwa model pembelajaran e-learning berbantuan media Edmodo memiliki pengaruh dalam meningkatnya kemampuan pemecahan masalah matematis siswa. Oleh karena itu penelitian ini bertujuan untuk mengetahui keefektifan pembelajaran matematika dengan model e-learning menggunakan Edmodo dalam meningkatkan kemampuan pemecahan masalah matematika.

\section{METODE}

Penelitian ini termasuk dalam jenis penelitian tindakan kelas (PTK). Penelitian ini memperoleh data dari hasil wawancara, observasi dan pemberian tes. Adapun penelitian dilakukan dalam tiga siklus dengan total sepuluh pertemuan. Subjek penelitian terdiri dari 6 orang siswa dari 34 siswa kelas XI IPS 2 SMA Negeri 2 Tambun Selatan yang telah dipilah berdasarkan tingkat kemampuan pemecahan masalah matematika. Analisis dilakukan secara deskriptif kualitatif dan kuantitatif. 


\section{HASIL DAN PEMBAHASAN}

\section{Siklus I}

Pelaksanaan tindakan pada siklus I dilakukan sesuai dengan yang telah direncanakan melalui RPP. Pengamatan selama kegiatan berlangsung dibantu oleh observer dan mengisi lembar observasi yang telah disiapkan. Pada pertemuan pertama sebagian subjek penelitian masih belum terlalu aktif dalam pembelajaran, tapi seiring berjalannya pembelajaran SP 1, SP 2, SP 4, dan SP 5 mulai menunjukkan perubahan sedikit saat mengerjakan soal latihan. Pada pertemuan kedua, subjek penelitian yang terlibat dalam proses diskusi bertambah meskipun pertambahan tersebut belum signifikan. Beberapa subjek penelitian masih memilih untuk bertanya melalui fitur chat dibandingkan dengan kolom komentar pada forum kelas agar tercipta interaksi aktif antar guru dengan siswa maupun interaksi antara siswa dengan siswa lainnya. Selama penelitian masih ditemukan SP 6 yang manggunakan aplikasi lain dalam bertanya kepada guru. Berdasarkan hasil tes akhir siklus I terdapat peningkatan nilai rata-rata keenam subjek penelitian. Nilai rata-rata yang diperoleh keenam subjek penelitian adalah 72,40. Namun jika dilihat persentase siswa secara keseluruhan yang tuntas dalam pelaksanaan tes akhir adalah $40 \%$. Persentase kategori kemampuan pemecahan masalah dari keenam subjek penelitian dapat dilihat pada Tabel 1.

TABEL 1. Hasil Tes Akhir Siklus I Keenam Subjek Penelitiam Berdasarkan Kategori Kemampuan Pemecahan Masalah Matematika

\begin{tabular}{cccc}
\hline No & $\begin{array}{c}\text { Kategori Kemampuan Pemecahan } \\
\text { Masalah Matematika }\end{array}$ & $\begin{array}{c}\text { Jumlah } \\
\text { Siswa }\end{array}$ & Persentase \\
\hline \hline 1 & Sangat baik & 2 & $33 \%$ \\
\hline 2 & Baik & 0 & $0 \%$ \\
\hline 3 & Cukup & 2 & $33 \%$ \\
\hline 4 & Rendah & 1 & $17 \%$ \\
\hline 5 & Sangat rendah & 1 & $17 \%$ \\
\hline
\end{tabular}

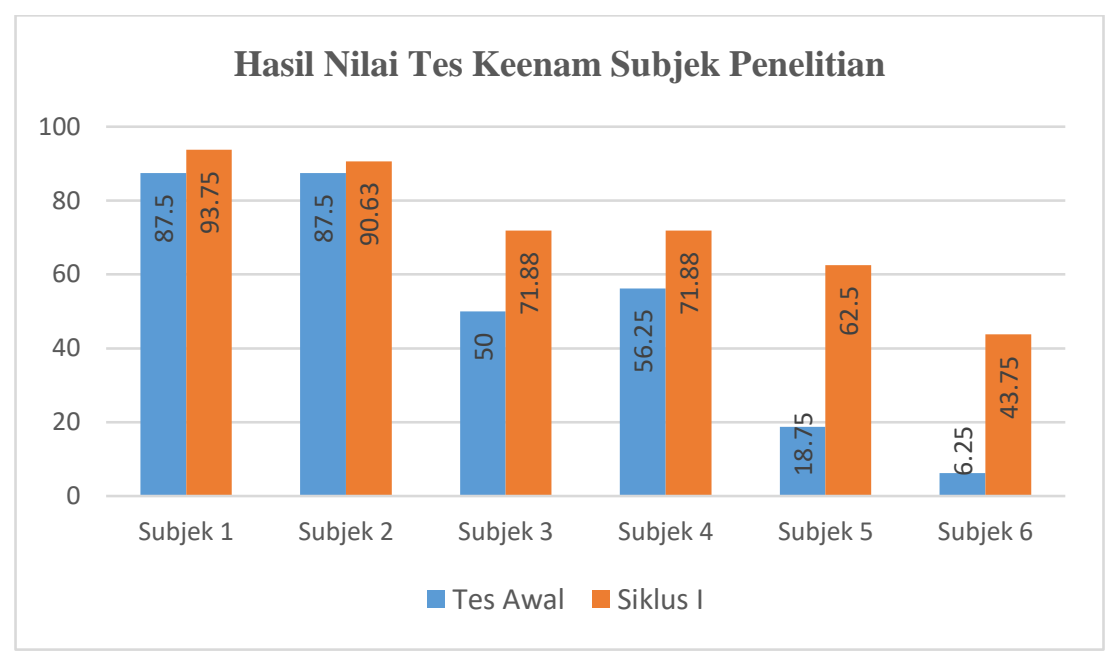

GAMBAR 1. Hasil Perolehan Nilai Tes Subjek Penelitian 


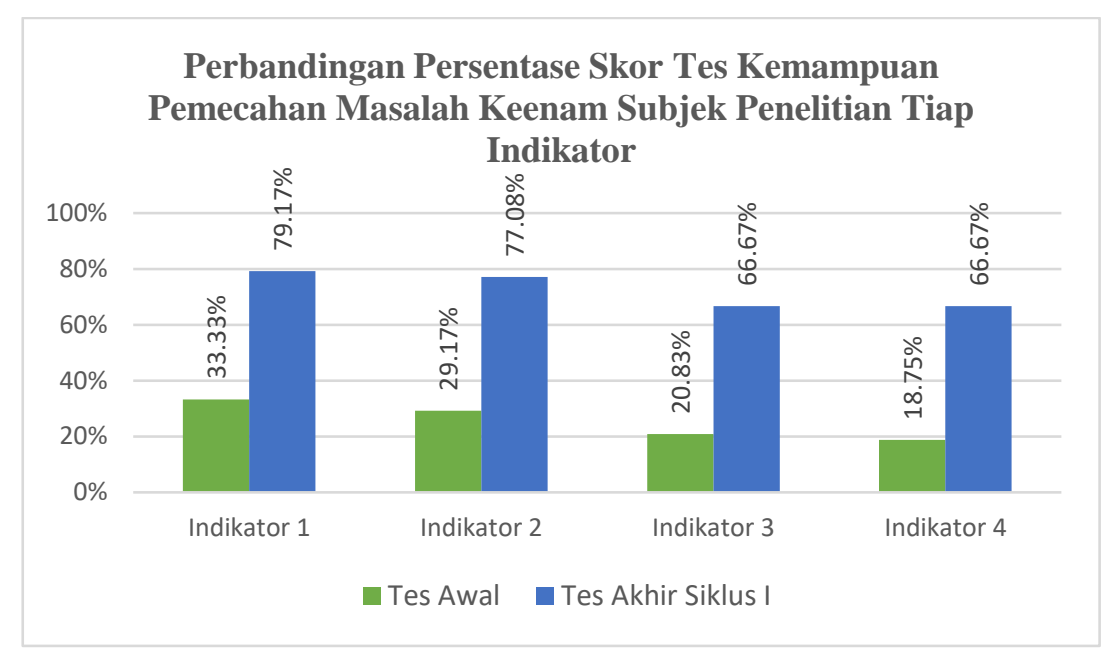

GAMBAR 2. Diagram Persentase Tes Tiap Indikator Kemampuan Pemecahan Masalah

\section{Siklus II}

Pelaksanaan tindakan pada siklus II dilakukan sesuai dengan yang telah direncanakan melalui RPP. Siswa didaftarkan ke dalam forum diskusi dalam kelas Edmodo dengan maksimal 9 orang siswa tiap forumnya. Pada pertemuan pertama beberapa subjek penelitian sudah mulai menunjukkan interaksi dalam pembelajaran, tapi belum seluruh subjek penelitian yang terlibat dalam aktivitas diskusi contohnya SP 6 yang hanya sesekali muncul dalam diskusi. Subjek penelitian juga antusias dalam mengikuti kegiatan games yang diadakan oleh guru melalui Edmodo. Namun selama pelaksanaan games masih terdapat tiga orang siswa yang belum bergabung dalam kegiatan tersebut karena permasalahan jaringan. Pada pertemuan kedua, siswa dalam kelas yang terlibat dalam proses diskusi bertambah meskipun belum keseluruhan siswa yang terlibat. Masih terdapat siswa yang memilih untuk menyimak percakapan yang dilakukan oleh siswa lainnya. Sedangkan subjek penelitian sudah mulai terlibat aktif selama pembelajaran, meskipun SP 5 dan SP 6 belum banyak membantu dalam proses pengerjaan tugas kelompok. Berdasarkan hasil tes akhir siklus II terdapat peningkatan nilai rata-rata pada keenam subjek penelitian. Nilai rata-rata yang diperoleh keenam subjek penelitian adalah 82,29. Namun persentase keseluruhan siswa yang tuntas baru mencapai $68,57 \%$. Dengan demikian perlu dilakukan perbaikan pembelajaran dengan mengadakan siklus III. Adapun persentase kategori kemampuan pemecahan masalah dari keenam subjek penelitian dapat dilihat pada Tabel 2.

TABEL 2. Hasil Tes Akhir Siklus II Keenam Subjek Penelitian Berdasarkan Kategori Kemampuan Pemecahan Masalah Matematika

\begin{tabular}{cccc}
\hline No & $\begin{array}{c}\text { Kategori Kemampuan Pemecahan } \\
\text { Masalah Matematika }\end{array}$ & $\begin{array}{c}\text { Jumlah } \\
\text { Siswa }\end{array}$ & Persentase \\
\hline \hline 1 & Sangat baik & 33 & $50 \%$ \\
\hline 2 & Baik & 1 & $17 \%$ \\
\hline 3 & Cukup & 2 & $33 \%$ \\
\hline 4 & Rendah & 0 & $0 \%$ \\
\hline 5 & Sangat rendah & 0 & $0 \%$ \\
\hline
\end{tabular}




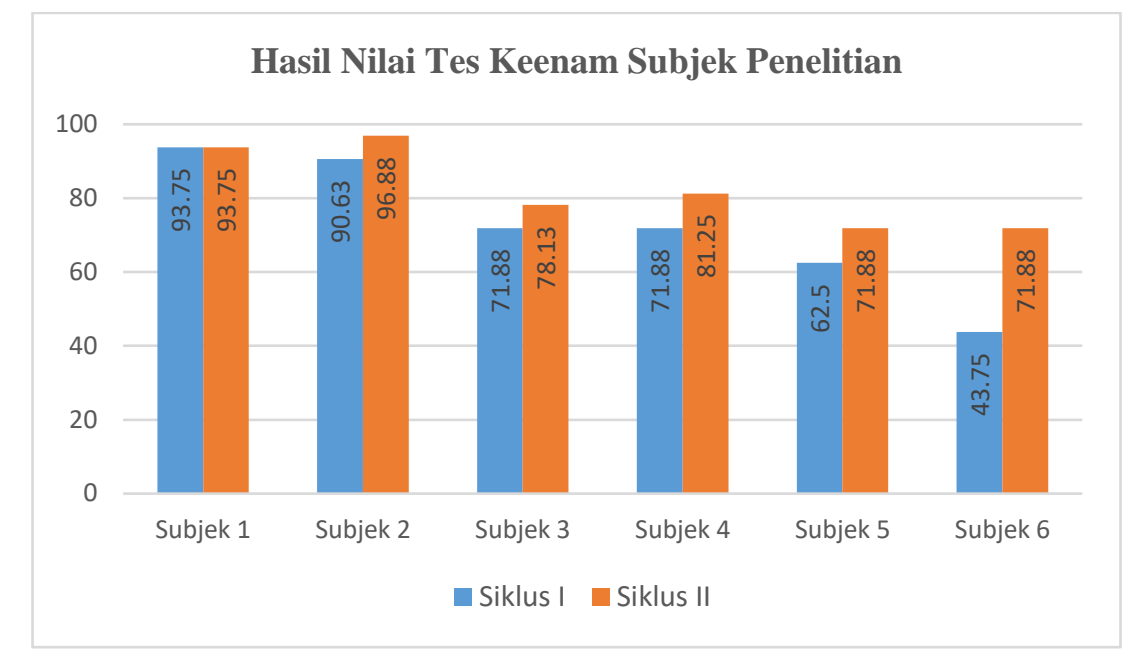

GAMBAR 3. Hasil Perolehan Nilai Tes Subjek Penelitian

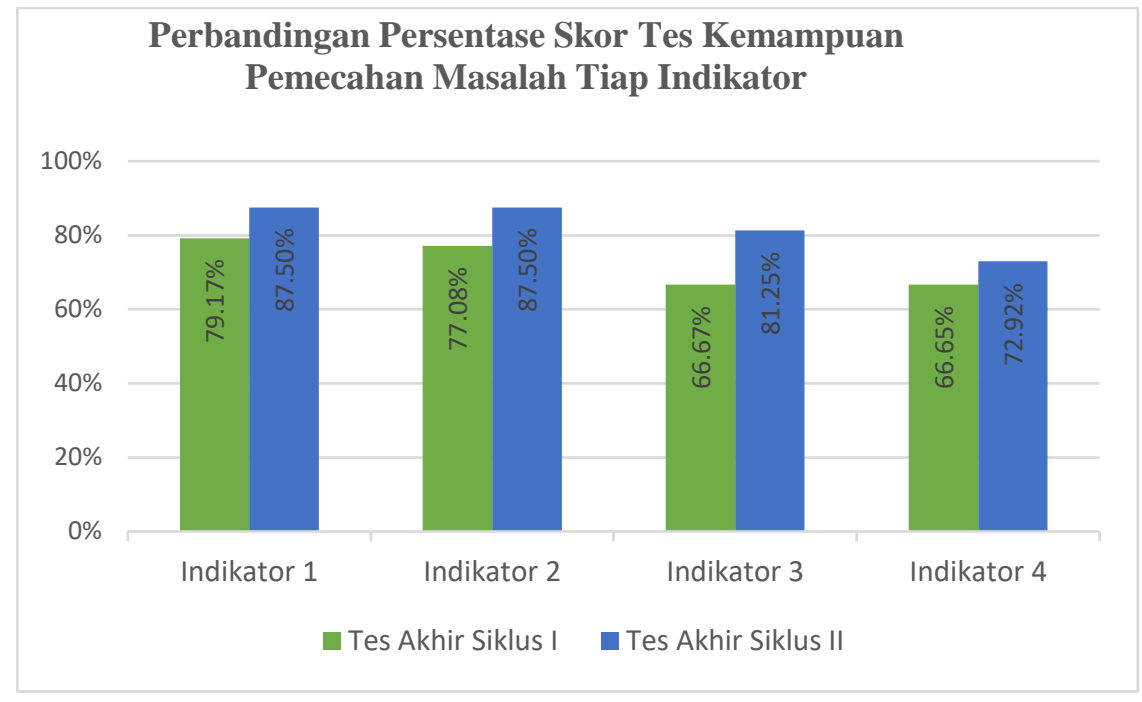

GAMBAR 4. Diagram Persentase Tes Tiap Indikator Kemampuan Pemecahan Masalah

\section{Siklus III}

Pelaksanaan tindakan pada siklus II dilakukan sesuai dengan yang telah direncanakan melalui RPP. Siswa didaftarkan ke dalam forum diskusi dalam kelas Edmodo dengan jumlah 4-5 orang siswa tiap forumnya. Pada pertemuan pertama kelima subjek penelitian sudah menunjukkan interaksi dalam pembelajaran, tapi SP 6 tampak belum terlibat aktif dalam kegiatan diskusi. Namun, SP 6 dan kelima subjek penelitian lainnya terlihat antusias dalam mengikuti kegiatan games yang diadakan oleh guru melalui Edmodo. Pada pertemuan kedua, subjek penelitian yang sudah aktif mengajak teman sekelompoknya agar turut terlibat aktif dalam proses diskusi. Proses diskusi juga sudah terlihat berjalan dengan baik karena setiap subjek penelitian sudah aktif dalam bertukar pikiran. Berdasarkan hasil tes akhir siklus III terdapat peningkatan nilai rata-rata keenam subjek penelitian. Keenam subjek penelitian berhasil memperoleh nilai di atas $\mathrm{kkm}$ dengan nilai rata-rata mereka adalah 87,50. Jika dilihat persentase siswa secara keseluruhan yang tuntas dalam pelaksanaan tes akhir adalah 82,86\%. Persentase kategori kemampuan pemecahan masalah dari keenam subjek penelitian dapat dilihat pada Tabel 3. 
TABEL 3. Hasil Tes Akhir Siklus III Keenam Subjek Penelitian Berdasarkan Kategori Kemampuan Pemecahan Masalah Matematika

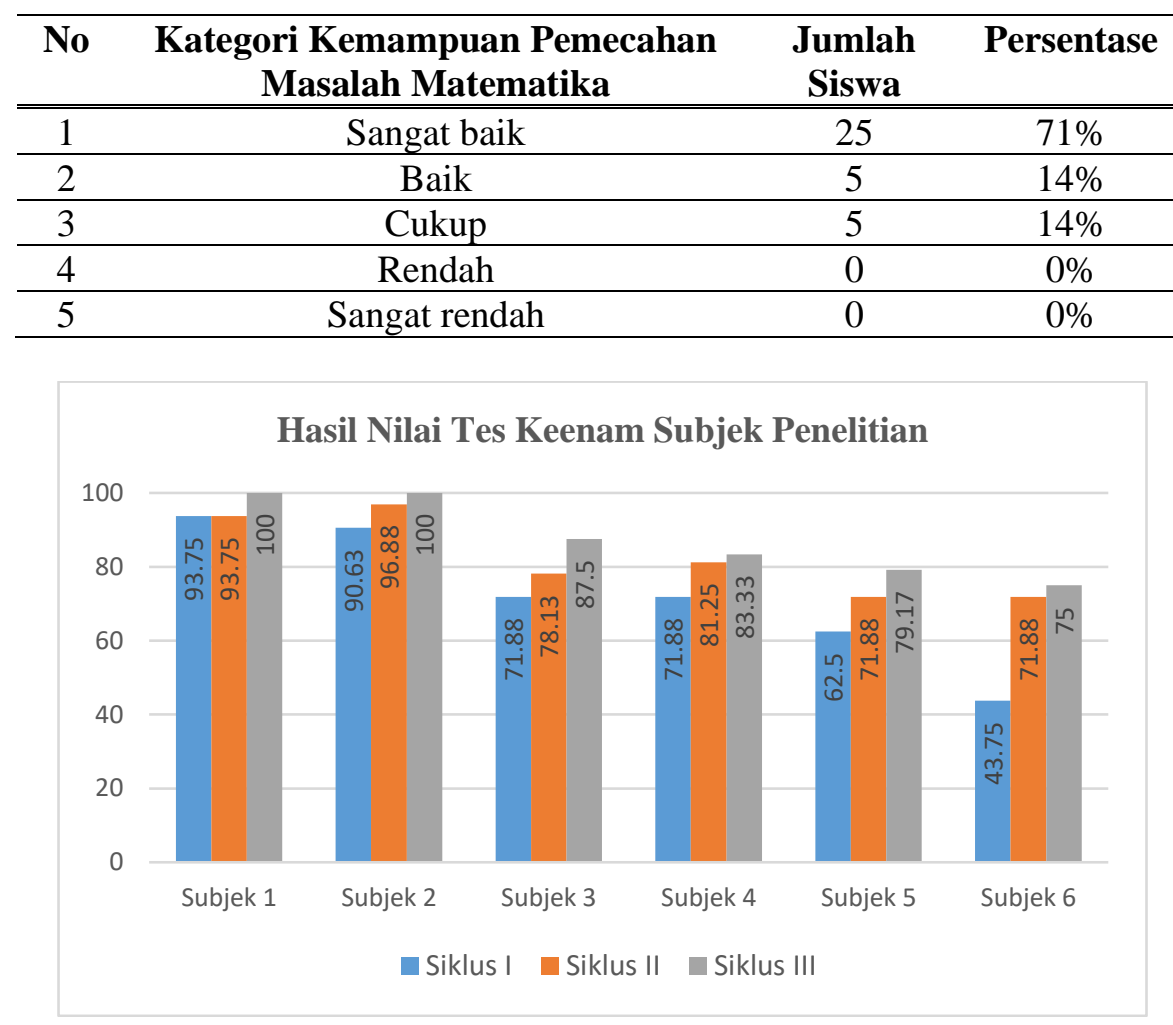

GAMBAR 5. Hasil Perolehan Nilai Tes Subjek Penelitian

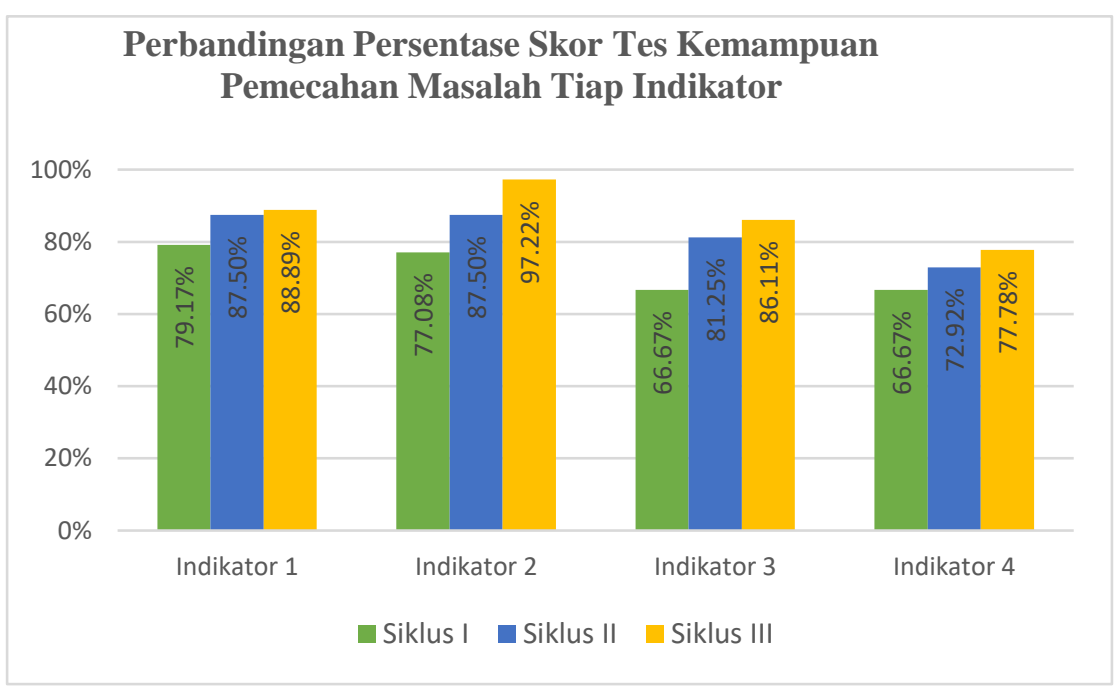

GAMBAR 6. Diagram Persentase Tes Tiap Indikator Kemampuan Pemecahan Masalah 


\section{Kesimpulan}

Keaktifan keenam subjek penelitian selama pembelajaran yang terus mengalami perkembangan baik dari penerapan tindakan pada siklus I hingga siklus III. Hal tersebut dapat dilihat dari hasil pengamatan selama tindakan dan pernyataan guru pada saat wawancara pasca melakukan tindakan. Suasana pembelajaran kian kondusif ketika pembelajaran dilakukan secara berkelompok dengan anggota tidak lebih dari 5 orang. Kegiatan diskusi pun dapat berjalan dengan baik. Kemampuan pemecahan masalah dari masing-masing subjek penelitian juga terus meningkat pada tiap pelaksanaan tindakan. Hal ini menunjukkan bahwa penggunaan Edmodo dalam pembelajaran matematika efektif dalam meningkatkan kemampuan pmecahan masalah matematika siswa.

\section{REFERENSI}

Hanifah, H., Supriadi, N., Widyastuti, R. (2019). Pengaruh model pembelajaran e-learning berbantuan media pembelajaran edmodo terhadap kemampuan pemecahan masalah matematis peserta didik. NUMERICAL: Jurnal Matematika Dan Pendidikan Matematika, 3(1), 31-42. https://www.journal.iaimnumetrolampung.ac.id/index.php/numerical/article/view/453 (diakses pada hari Senin, 14 Desember 2020 pukul 22.05)

Polya, G. (1957). How to Solve It: A New Aspect of Mathematical Method, $2^{\text {nd }}$ ed. Princeton: Princeton University Press.

Rintaningrum, R. (2016). A model of school learning the use of Carrolls' Model of foreign language learning. International Symposium For Modern School Development, Social Science and Applied Technologies, 43-46. http://digilib.uinsby.ac.id/6881/13/Prosiding\%20ISMOSAT.pdf\#page=49 (diakses pada hari Jumat, 11 September 2020 pukul 16.49)

Rohmawati, A. (2015). Efektivitas pembelajaran. Jurnal Pendidikan Usia Dini, 9(1), 15-32. http://journal.unj.ac.id/unj/index.php/jpud/article/view/3491 (diakses pada hari Jumat, 28 Agustus 2020 pukul 17.51)

Yustinaningrum, B. (2018). The implementation of e-learning web-based model centric course (edmodo) toward the mathematics' interest and learning outcomes. Al-Jabar : Jurnal Pendidikan Matematika, 9(1), 25-32. http://ejournal.radenintan.ac.id/index.php/al-jabar/article/view/2175 (diakses pada hari Selasa, 14 April 2020 pukul 18.20) 